\title{
Challenges and Implementation of Financial Institutions Development Policy in Laos on 2016-2020
}

\author{
Maliny Sourigna ${ }^{1}$, Shuzhen $\mathrm{Zhu}^{1}$, Syed Ahtsham $\mathrm{Ali}^{1}$ \\ ${ }^{1}$ Glorious Sun School of Business and Management, Donghua University, Shanghai, China \\ Correspondence: Maliny Sourigna, Glorious Sun School of Business and Management, Donghua University, \\ 1882 Yan'an West Road, Changning District,200051,Shanghai,China.
}

Received: September 11, 2017

doi:10.5539/ibr.v11n1p115

\author{
Accepted: December 6, 2017 Online Published: December 19, 2017 \\ URL: https://doi.org/10.5539/ibr.v11n1p115
}

\begin{abstract}
This study focuses on the financial system development policy in 5 years of the Lao PDR which referring to "Lao strategic financial system development plan 2016-2025 and vision to 2030". The main policies include the upgrading and implementation of the supervision system, innovation in financial infrastructures with effective risk management, develop and stabilize banking system and non-banking financial institutions. Increasing number of the listed company and financial products creates diversification in the capital market. From the synthesizer environment and current situation of financial development in the country, the policy implementation challenges are analyzed from empirical environment of financial system in the country. Additionally, other challenges on supervision tools, under capitalization, less product types, small size of capital market, and risk management challenge which came from unconnected information system and uncompleted of related institutions are also discussed. Moreover, effective policy to address the challenges and the missing points for further policies are also discussed.
\end{abstract}

Keywords: laos, financial institutions, system stability, development policies

\section{Introduction}

After the end of second Indo-china War (Vietnam War), Lao's People was proclaimed with democracy on $2^{\text {nd }}$ December 1975. The party and government started to develop a social-economic, industrial and financial system for the whole country. In 1986, following to the resolution of the $15^{\text {th }}$ Congress of the Lao People's revolution, a newly emerged guideline of the economic and financial reform was carried out. The government implemented the new economic policy and open the country to the foreign investment. Then in March 1988, the government issued an agreement of banking system transformation. The major transformation of Bank of the Lao PDR (BOL) to the central bank was the transition from mono-banking system to two tiered banking system in 1989. This helped to improve the responsibility and consistency needed for the economic development, provided the flexibility to guarantee the monetary stability at the macro level.

During the last 15 years (2001-2015), Lao Financial Institutions had been continuously improved and de veloped with regard to quantity and quality. The commercial banks operated base on business regulation. There was two improvement of organizational structure and a notice of commercial bank in 2007. The commercial banks had been grown and included various types such as state-owned banks, private banks, joint-investment banks, foreign owned banks, foreign owned branch banks, and a policy bank. The banking sector became more competitive and the main factors of development and modernization. In addition, non-bank financial institutions were established around the country, for instance, microfinance institutes, pawn shop and leasing company, Lao Securities Exchange market.

\section{Literature Review}

From "Web of Knowledge" search results of financial stability policy showed that cited numbers of the relating article increasing every single year (Fig.1), which demonstrates more and more authors and research institutions pay attention in financial system stability and policy reform area. Highest cited papers have been published during 2000-2011. To overview some high cited articles from the list of highest time cited on Web of Science, and including recent articles published in SSCI journals would conduct effective result for implementation challenges and policy discussion in this context. Other than, there is only one researching article of Lao Finance 
in "Web of Science", and few papers have found from other sources. Thus, author would mainly overview some existed articles or research papers related to the financial system development policy of Lao PDR.

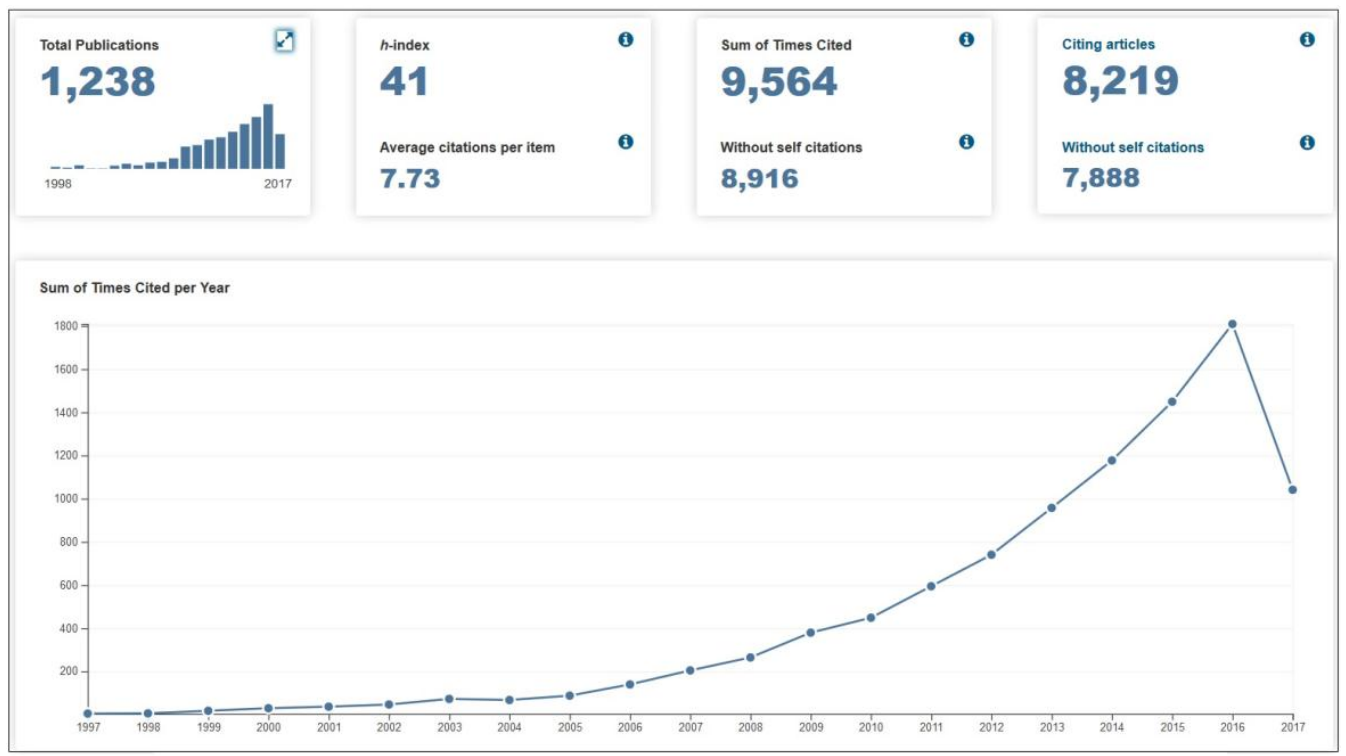

Figure 1. Graph of citation report of 1,238 relating articles within Web of Science

As acknowledged in last two-decade literature, the financial system plays a crucial role in economic development (Levin, 1997). In Asian developing countries, including Lao PDR, the financial development promotes the economic growth (Habibullah, 2006). A result of the positive correlation between Lao financial development and economic growth has emphasized the importance of financial system development (Vonsengchanh, 2013). Moreover, the economic growth in many different aspects of financial system dominant has played a role, such as which type of financial institutions should be established, the design of the regulatory and supervisory system, and the government policies for promoting the growth of financial system (Hermes, 2000). Moreover, effective financial system stability concerned by the choice for the type of financial institutions to be established, regulatory and supervisory design and the choice for policies making. Various studies suggested that stock market and play the important role to the financial system in transition economies, both banks, and the stock market could promote economic growth (Charemza \& Majerowska, 2000; Arestis, 2001). It depended on a government in that country would choose a bank oriented or market oriented system for leading financial system growth. For banking oriented leading the financial system, the higher interest rate charged to loan customer who was higher risk, banks risk would not higher if they increase their equity capital and engages in efficiency risk-mitigation techniques (Berger, 2009). The research of banking stability policy making and regulation circle have been done by many experts such as Allen \& Gale (2004); Berger et al.,(2004); Berger, Klapper, et al., (2004); Beck et al.,(2010); Martinez \& Repullo(2010); Wagner(2010). Additionally, the global financial crisis in last decade has highlighted the importance to stabilize financial system through improving the regulation and supervision of financial institutions. Recently, main aspects of the regulatory reforms concentrating in measuring and regulating systemic risk. Arnold analyzed challenge of the monitory financial system, detected of vulnerability which might lead a further financial instability, indicating the way to set the prudential policies (Arnold, 2012). A danger of contagion could cause bank failure, at the same times, the contagious defaults could break down the substantial fraction in the banking system, and imposing higher a cost to society. Lesson learned on an interaction of common shocks and contagion is needed.

In ASEAN Regional Forum countries, a researching result presented the policy implemented in the banking sector, the stock market, bond market and insurance market development is important for both financial development and economic growth of ARF countries (Pradhan, 2017). In the other hand, cross countries studied on central bank regarded policy framework to ensure the financial stability, a transparency policy and legal origin matter positive effect to financial stability in 110 countries (Horvath, 2016).

For the Lao PDR, financial sector reform has been implemented by prudential on regulation and supervision system which based on financial liberalization and institutional reforms. This action began in the late-of 80s (Brownbridge, 1999). Bank sector reform is one of the main parts in econo mic reform policy. Keovongvichith (2012) overviewed the Lao banking system structure and development in last two decades. The key of financial 
development indicator had been investigated before using CAMELS system to analyze the financial performance of banking institutions. The results suggested the authority (BOL) to comprehend the strength and fragility of the banking sector, referring to formulate effective policies and strategies for promoting sound banking system. The Lao PDR is developing the financial system under the government decree" Lao strategic financial system development plan 2016-2025 and vision to 2030" which had been draft by BOL (2015). IMF Country Report (2012,2017)"Lao PDR 2012 article IV consultant" and "Lao PDR 2017 article IV consultant" has discussed the policy for ensuring a sound banking system in Laos, discussed on improving supervision, banking sector risk, crisis management framework, reduce dollarization.

\section{Overall of Lao Financial Institutions Development Situation and Policy Implementation in 2001 -2016}

The financial system in Laos was deeply developed and intensely expanded under the supervision system especially the BOL supervised the commercial bank by using CAMEL approach, improve the organizational structure of the state-owned bank in 2003 and promulgated the commercial bank law in 2007. Moreover, many offices and legal action were implemented such as Nayobay Bank was established in 2007, the Anti Money Laundering Intelligence Unit was established in 2008 and the agreement on capital expansion was released in 2009 and the Lao Securities Exchange was established in 2010. In addition, the BOL continuously develop the hedging system for financial institutions such as deposit protection fund (1999), credit information center (2001) , Inter-Bank Money Market (2016). As a result, the financial institutions were strengthened and become the source of capital raising and allocated capital to the economy and indirectly and directly increased the role of the financial system to preserve and develop the mission of the nation.

The banking sector was the main element of the financial system in Laos. It was the main component economic stability and socio-economic development regarding the government policies. Banking sector consistently stabilized the monetary and it revealed of $4.02 \%$ on the average of inflation from 2012 to 2017. It was also the main actor for allocate funding to public and private production sector and to contribute the national economic growth with the average of $7.58 \%$ from 2011 to 2017 (Fig.2).

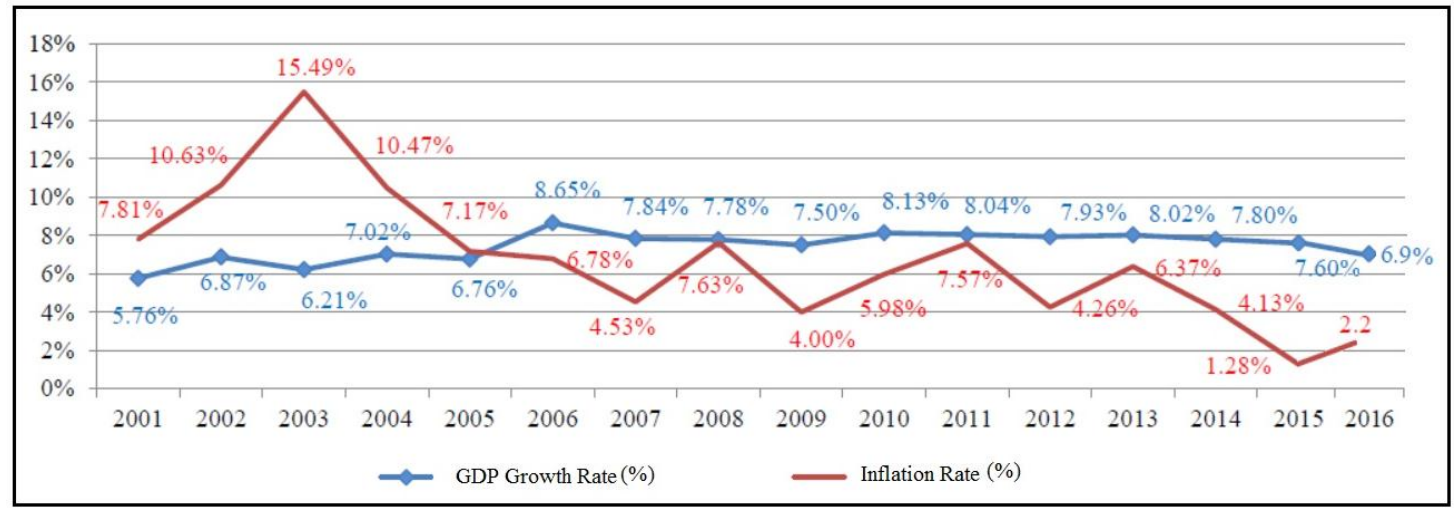

Figure 2. Real GDP Growth and Inflation rate of The Laos PDR in 2001-2016

\subsection{Commercial Banks Development}

The Commercial banks were growing and expanding through the country especially after the operation of the foreign banks in other provinces. This significantly increased the access of financial service. In addition, the ownership and type of business were widely opened and that increased number of private bank, joint-investment and branches of the foreign banks to 25 banks from 2001. There were more competition and de velopment among banking system and the innovated of multiple and modern products by using new risk management tools. There were 40 banks, 89 branches and 460 service unit in 2015. The capital strength ratio consistently increased up to $19.23 \%$ and total asset increased from 4,451.11 billion Kip in 2001 to $94,988.98$ billion Kip in 2015. During 5 years (2011- 2015), the commercial banks had contributed the net credit was $28,792.51$ billion Kip, short term credit was $25.21 \%$, medium term credit was $49.81 \%$ and long term credit was $24.98 \%$. Most of the credit was provided to trading business which accounted for $18.54 \%$, construction accounted for $16.60 \%$ and industry accounted for $15.59 \%$ of total credit. The capital raising grew from 2,597.60 billion Kip in 2001 to 59,754.32 billion Kip in 2016 (Figure 3). 


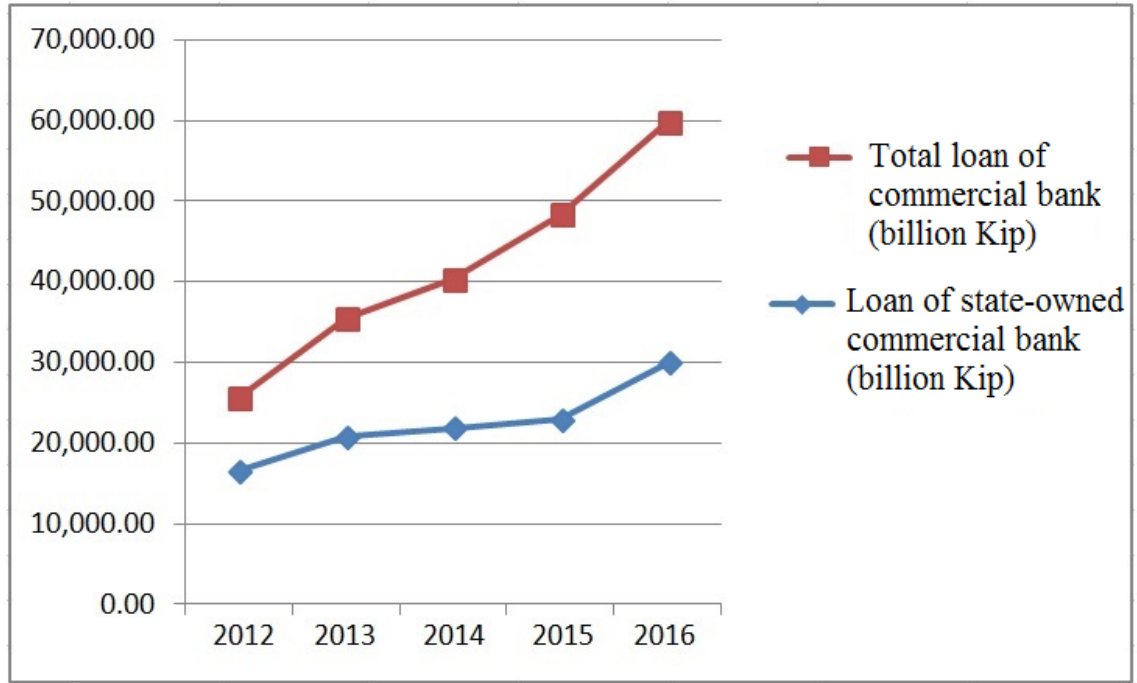

Figure 3. Total of commercial bank and state-owned commercial bank credit

\subsection{Policy Bank Institutions}

During 2007-2015, the Nayobay Bank provided credit for poverty reduction and support production. The credits were given to poor district accounting for 2,153.09 billion Kip, 3 Sang Village accounted for 260.02 billion Kip and government attention village accounted for 202.74 billion Kip. A bank was able to achieve a quality of credit. The over limited of debt decreased from $42.55 \%$ in 2001 to $3 \%$ in 2015.

\subsection{Non-Bank Financial Institutions}

Non-bank financial institutions had been grown since 2001. There were 142 financial institutes in 2015. From 2010 to 2015, total asset increased from 104.5 billion Kip to 673 billion, capital raising increased from 29.7 billion Kip to 298 billion Kip and providing credit to society increased from 49.21 billion Kip to 435.37 billion Kip. Half-formal micro finance such as village development fund, group fund, and village bank had been grown with a better condition to access to finance around the country. The connection of depositor had been constantly improved after the establishment of depositor protection fund. The members increased from 7 banks in 2001 to 36 banks in 2015 and the fees were collected with a total amount of 163.39 billion Kip; however, financial institutes have not yet been the member of Depositor protection fund.

In addition, the debt purchasing center bought Non-Performing Loan from commercial bank 20 projects with the value of 93.76 billion Kip and collected 73.79 billion Kip within 7 years (2008-2015).

\subsection{Capital Market}

Lao securities exchange (LSX) is only one stock market in the country, which has been established on 10th October 2010 and operated in 11th January 2011. LSX is efficient investment alternative, effective long-run fund mobilization and excellently back as another "leg" of the Lao financial market pushing on the most remarkable performances of Lao economic development. Since 2010, LSX approved 3 IPOs with total fund raised 4753 billion Kip (about 594 million USD) amount $5.74 \%$ of GDP (2013). Banking sector raised 35,424 billion Kip (about 4,428 million USD) account for 42.82\% of GDP (2013). In end of 2016, Market Capitalization: 10.41 billion Kip (about 1.3 million USD). 
Table 1. Table of Laos Capital Market Proformance

\begin{tabular}{|c|c|c|c|c|}
\hline \multirow{2}{*}{$\#$} & Index & Trading Value & \multicolumn{2}{|c|}{ Number of investor account } \\
\cline { 4 - 5 } & & (bilion Kip) & Domestic & foreign \\
\hline 2012 & $1,223.92$ & 124.79 & 7,339 & 1,571 \\
\hline 2013 & $1,253.89$ & 188.89 & 7,637 & 1,829 \\
\hline 2014 & $1,397.69$ & 156.32 & 9,154 & 2,218 \\
\hline 2015 & $1,173.63$ & 200.19 & 9,654 & 2,424 \\
\hline 2016 & 1.014 .55 & 113.52 & 9,906 & 2,511 \\
\hline
\end{tabular}

Source: Ms Phetsamai Inthapanya, Laos Securities Commission office report: Capital market development in Laos

In 2017, there are five listed companies in the stock market such as Banque Pour Le Commerce Exterior Lao Public (BCEL), EDL Generation Public Company(EDL-Gen), Lao World Public Company(LWPC), Petroleum Trading Lao Public Company(PTL) and Souvanny Home Center Public Company(SVN). The capital market participants are shown in Fig.4

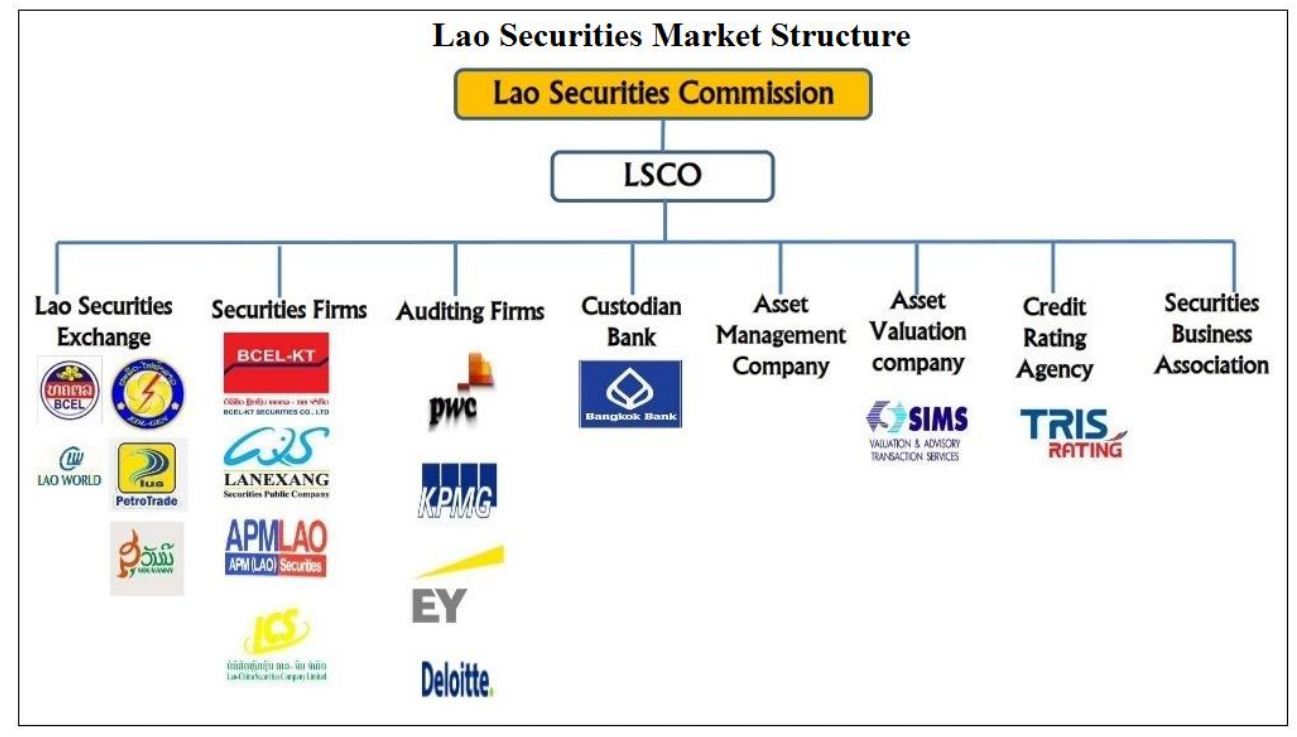

Figure 4. Lao Securities Market Paticipants

\section{The Financial Institutions Development Policy in the Next 5 years}

For the financial system stabilizing and development, The BOL has completed a draft "Lao strategic financial system development plan 2016-2025 and vision to 2030", this document has been accepted and enabled as the government decree, undersigned by the prime minister of the Lao PDR in 19th Aug 2016. This document has suggested that 5 years of the financial system development policies range were subscribed as below.

\subsection{Policies}

The Financial system is continuously operating and improving when it is necessary to strengthen and support the consistency growth. The Financial system aims to maintain sustainability and contribute to the socio-economic by controlling the overdue debt not exceed 3\% and ensure the capital sufficiency accordingly the determined in the regulation and eager to upgrade at least one the state-owned bank to get the Qualified ASEAN Bank $(\mathrm{QAB})$.

\subsection{Financial Instruments Development and Supervision Implementation}

First of all, financial instruments development should be done by systematically and constantly develop the financial instruments to follow up the activity of bank such as legal action and create key indicators on assurance and caution beforehand. Transferring banks system supervise which base on CAMEL to the Basel Core Principle 
for Effective Banking System aiming at the banks in Lao PDR to consistently operate under Basel II principle and some terms of Basel III. The Financial supervision framework and policy implementation are running by the relevant departments as Fig.5.

In the other hand, the BOL encouraged to research and improve financial instruments for completely and promptly monitor the operation of Non-bank finance institutions. The authorities and financial institutions might prepare for the Financial Sector Assessment Program and bring the result from this project to be the reference for suitable to further development policy of financial instruments.

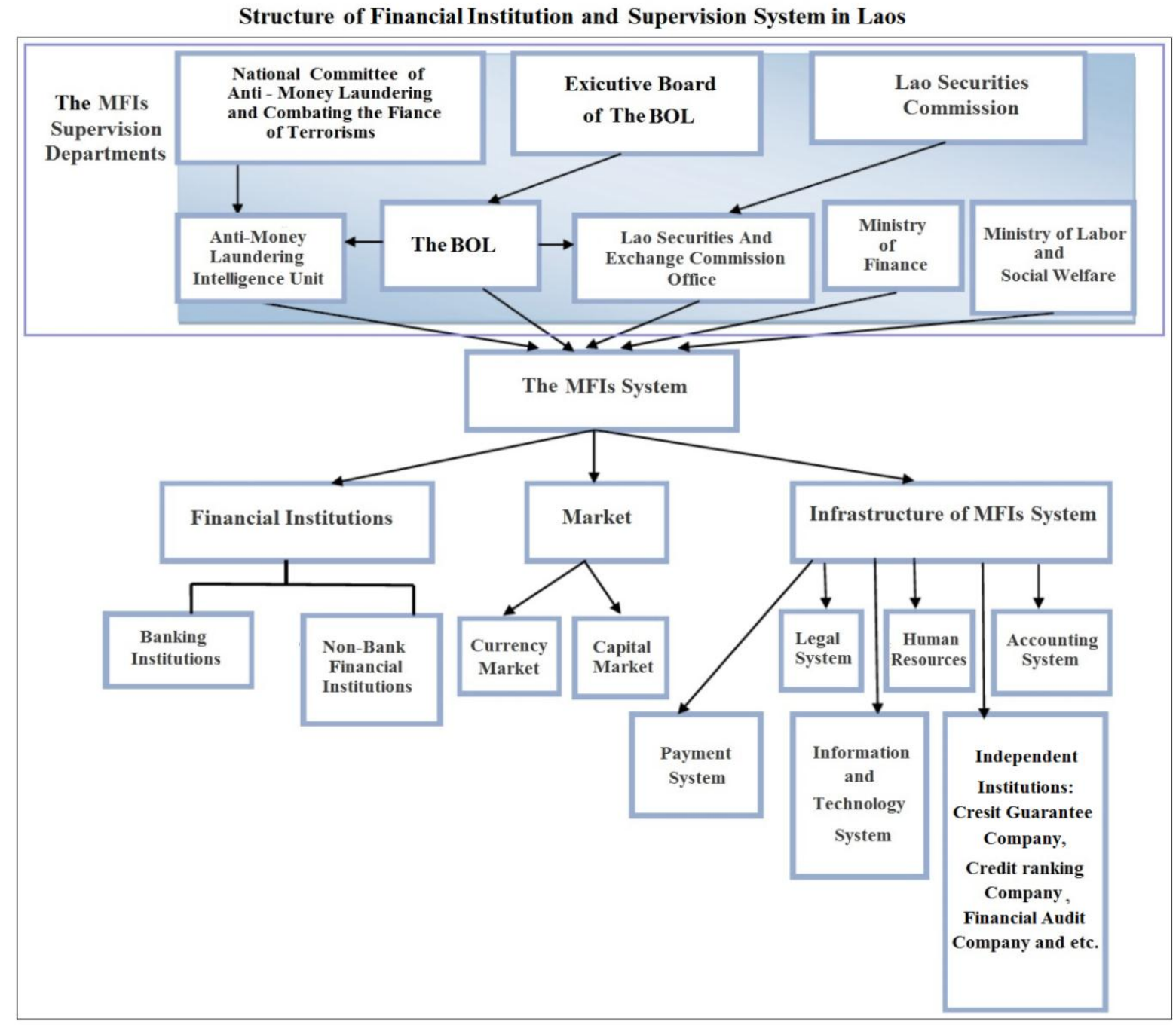

Figure 5. Map of Financial structure and Supervision system of the Lao PDR

\subsection{The Financial System Development and Stability}

Developing financial system started by improving the structure of state-owned bank to be stronger. At the same times, regularly assess the growth of commercial bank for lessons learned. In addition, revising the term and condition of commercial bank licensing with the higher standard for chosen investors as well-known and powerful banks. Encourage understanding and unity on the Basel standard for ensuring the implementation in a whole banking system.

Continuously promote the bank institutes and the non-bank financial institutions (NBFI) into the supervision of the BOL for sustainable development and progress; for instance, diversified service and high-effectiveness service for response to society demand.

\subsection{Risk Management}

Empowerment the depositor protection fund framework, increasing the number of members including bank institution and non-bank financial institutions, set up risk warning and safeguard system for protecting members from bankruptcy, develop the flexible and modern mechanism and repayment system to depositors by using 
proficient capital management and assured stability. Furthermore, studies on conditions and necessaries in order to apply for attending International Association of Deposit Insurers (IADI).

The authority cooperated with relevant institutions to establish the revolving domestic and foreign institutions for ensuring the risk management and the financial stabilizing such as credit ranking institutions, credit guarantee institutions, property management bank, financial consumer protection organization and asset assessment institutions. In addition, restructuring the credit information, debt acquisition center and bills storage center to be independent of funding would be required.

\subsection{Capital Market Development}

Starting from security market developing from expanding the number of listed companies by cooperating with relevant departments, to support and providing the suitable condition for requiring capital enterprises to be able to raise their capital in the securities market. The market should provide diversification of financial products such as corporate bonds, Government bonds and etc. At the same times, increasing the number of investors especially the domestic and foreign institutions investors.

Improving supervisory framework in securities. at the same time, the infrastructures development in securities market become the effective organization and complete all elements in the securities supervisory framework, with enhancing on training and advertise securities trading to society.

\section{Challenges}

The authority and IMF country reports in early of 2017 have shown that financial de velopment policy outlook and implementation needed to address financial development constraints such as:

- Supervision tools and stabilizing assessment of financial are inadequate, lacking standard principle or mechanism in supervision track and assess in financial institutions such as a tool for testing strain level of a system "Stress Testing", system crisis warning "Early Warning System". For preventing system from common shocks, systemic risk and risk contagion(Arnold,2012)

- Hugh amount of loans for the country developing are necessary, but the source of the bank capital mostly are short term deposits, with the less attractive product, competition between banks only based on interest rate. Therefore market interest rate not suitable for fundamental of economic growth.

- Banking institutions and other credit institutions such as microfinance institutions could face non-performing loans (NPL) rate increasing problem, but still higher than required range. Unexpectedly, state-owned bank balance sheets show signs of weakness, with rising non-performing loans (NPLs) and weak capital and profitability.

- A small size of the capital market, existing low liquidity and fewer product types, which are fewer attractive to the investor and investing demander.

- Risk management system is uncompleted from lack of relevant institutions for ensuring the effectiveness of the financial system operation and some institutions still fulfill, for examples Credit ranking institution, Credit guarantee institutes, Finance consumer protection organization, Asset valuable institutes etc. Challenge of the risk also came from poor information network connection among the financial institutions, especially credit information system, an individual system in each bank institution, and disconnect with public securities system in the country.

\section{Policy Discuss}

The Lao PDR's 10 years, financial development strategy has included the policies which effective addressing challenges and solving the financial developing obstruction problems. The Country Report No 17/53 of International Monetary Funds (IMF) has also discussed the addressing of Lao financial system weakness in capitals, profitable abilities, and performance of bank sectors in Laos, which providing effective policy reference in the future. From two documents studying, for addressing the challenges and solve the obstructed problems, the main policy recommendations for the financial developing as below:

- The supervision tools were based on CAMEL system and Basel I, transferring to the Basel Core Principle for Effective Banking System to improving the supervision for higher bank performance, consistently operate under Basel II principle and some terms of Basel III. Finance soundness indicators (FSIs) would be used in the financial system, setting up the simulated for Stress Testing Model and creating Early Warning System are necessary. Strengthened financial supervision by investigating and assessing the commercial banks if they following supervision rules and regulations. 
- Undercapitalization of banking sector, especially the state-owned banks should recapitalize. IMF suggested to improving the regulations and supervision, considered in establishing the capital buffer in commercial banks. The BOL amendments the regulations about overseas funding of commercial banks for support domestic loan and ensure the repayment ability of the bank institutions.

- The rise in nonperforming loans (NPLs) should promptly address by strengthening sound lending practices and supervision, step by step eliminating the regulatory forbearance, recapitalizing to the state-owned banks and addressing supervisory weaknesses are very important. Financial Action Task Force encouraged to full implementation for supervisory plan. Many experts suggested that the authorities should estimate the challenges in the implemented result of regulation and supervision reforms (Berger, 2009; Arnold, 2012).

- From capital market development policy, providing the suitable condition for enterprises to list in the stock market would expand numbers of the listed companies, which enlarge security market size. In the other hand, diversified financial products and services in order to promote competition, attractive to domestic and foreign dependent investors and institutions investors. Improving securities market infrastructures and supervision, promote Lao securities trading to domestic and foreign market are needed.

- As Hermes suggested to establish the revolving institutions for controlling the risk management and the financial stability development, for instance, credit ranking institutions, credit guarantee institutions, property management bank, financial consumer protection organization and asset assessment institutions and other relevant organizations. Improving the credit information system and network connection in the whole country are necessary.

\section{Concluding Remarks}

The formers studied have concerned the important of financial system, as well as institutions stability and development. To achieve that goal, many formers have suggested effective policy making, policy tools and implementation, including the financial institutions development obstructed problems in Lao PDR and foreign countries.

The financial institutions development policy of Laos from 2016-2020 focus on updating the supervision framework and implementation tools; stabilized and developed the financial institutions, especially robust banking system; capital market development; how to develop financial infrastructures and improving risk management. Systematically and entirely set of this policy were crucial and necessary for the financial institutions development.

In this context pointed out the financial system development challenges analyzing from the current financial institution developing situation and policies implementation practicing, for instance, lacking of stress testing system and crisis warning system, undercapitalization and NPL higher than regulation rate, risk management in financial institutions, the small size capital market and fewer type of products. Some of challenges addressing has been described in 5 years policy, and the others have concluded from the formers research results from IMF Report, Hermes, Berger, Arnold etc., to recommend for further policies referencing.

\section{References}

Andrianova, S., Demetriades, P., \& Shortland, A. (2012). Government Ownership of Banks, Institutions and Economic Growth. Economica, 79, 449-469. https://doi.org/10.1111/j.1468-0335.2011.00904.x

Arnold, B., Borio, C., Ellis, L., \& Moshirian, F. (2012).Systemic risk, macroprudential policy frameworks, monitoring financial systems and the evolution of capital adequacy. Journal of Banking \& Finance, 36, 3125-3132. https://doi.org/10.1016/j.jbankfin.2012.07.023

Bank of the Lao PDR. (2016). Monetary statistic report. Retrieve from https://www.bol.gov.la/english/financial_statistics.html

Bank of the Lao PDR. (2016).Financial Statistics Report of the IV Quarterly 2016.

Bank of the Lao PDR. (2016).Lao Strategic Financial System Development Plan 2016-2025 and Vision toward 2030. The Decree No 316/Lao Government 19 August 2016.

Berger, A. N., Klapper, L. F., \& Turk-Ariss, R. (2009).Bank Competition and Financial Stability. Journal of Financial Services Research, 35(2), 99-118. https://doi.org/10.1007/s10693-008-0050-7

Chanthachack, S. (2014). Laos Securities Commission report: Capital market development in Lao PDR. Retrieve 
from http://www.asiasecuritiesforum.org/pdf/2015/SaysamoneChan thachack_s.pdf

Charemza, W., \& Majerowska, E. (2000). Regulation of the warsaw stock exchange: the portfolio allocation problem. Journal of Banking and Finance, 24(4), 555-576. https://doi.org/10.1016/S0378-4266(99)00080-1

Hermes, N., \& Lensink, R. (2000).Financial system development in transition economies. Journal of Banking and Finance, 24, 507-524. https://doi.org/10.1016/S0378-4266(99)00078-3

Horvath, R., \& Vasko, D. (2016). Central bank transparency and financial stability. Journal of Financial Stability, 22, 45-56. https://doi.org/10.1016/j.jfs.2015.12.003

International Monetary Fund. (2012).The Lao's People Democretic Republic 2012 Article IV Consultation, IMF Country Report No.12/286.

International Monetary Fund. (2017). The Lao's People Democretic Republic Staff Report For The 2016 Article IV Consultation-Informational Index, IMF Country Report No.17/53.

Inthiphanya, P. (2016).Lao Securities Commission Office, staff report: Capital Market Development in Laos. Retrieve from http://www.fsa.go.jp/en/glopac/Capital_Market_Development_in_Lao_PDR.pdf

Keovongvichith, P. (2012).An Analysis of the Recent Financial Performance of the Laotian Banking Sector during 2005-2010. International Journal of Economics and Finance, 4(4), 148-162. https://doi.org/10.5539/ijef.v4n4p148

Marks, S. V. (2011).Lao economic policies and effective rates of protection. Journal of Asian Economics, 22, 115-127.https://doi.org/10.1016/j.asieco.2010.11.002

Pradhan, R, P., Arvin, M, B., Bahmani, S., Hall, J, H., \& Norman, N, R. (2017). Finance and growth: Evidence from the ARF countries. The Quarterly Review of Economics and Finance. https://doi.org/10.1016/j.qref.2017.01.011

Sayvaya, I., \& Kyophilavong, P. (2015). Does microfinance reduce poverty in Lao PDR? International Journal of Development Issues, 14(3), 215-230. https://doi.org/10.1108/IJDI-10-2014-0072

Note: Official and Parallel Market Exchange Rate(LAK/1USD)

\begin{tabular}{lc}
\hline year & reference rate(Average) \\
\hline 2011 & $8,028.96$ \\
2012 & $8,007.18$ \\
2013 & $7,860.64$ \\
2014 & $8,057.55$ \\
2015 & $8,150.36$ \\
2016 & $8,181.33$ \\
\hline
\end{tabular}

Source: The BOL Monetary Statistic Quaterly Report IV 2016

\section{Copyrights}

Copyright for this article is retained by the author(s), with first publication rights granted to the journal.

This is an open-access article distributed under the terms and conditions of the Creative Commons Attribution license (http://creativecommons.org/licenses/by/4.0/). 